\title{
DISINFECTION OF AIR AND DUST IN FATTENING HOUSES FOR CHICKENS BY LACTIC ACID AEROSOL
}

\author{
A. FIŠER \\ Department of Prevention of Pig Diseases, Animal Breeding and Animal Hygiene, University \\ of Veterinary Science, 61242 Brno
}

Received October 13, 1978

\begin{abstract}
Fišer A.: Disinfection of Air and Dust in Fattening Houses for Chickens by Lactic Acid Aerosol. Acta vet. Brno, 47, 1978: 173-183.

In laboratory trials, lactic acis administered in form of aerosol in doses of 720$-787 \mathrm{mg} / \mathrm{m}^{3}$ devitalized Pseudomonas and E. coli strains within 30 minutes, Streptococcus strains within 48 hours following the treatment.

In trials carried out in housings with chickens kept on bedding, amounts of $1,535 \mathrm{mg}$ lactic acid pet $1 \mathrm{~m}^{3}$ were administered on days 15 and 25 respectively, and, of $420 \mathrm{mg} / \mathrm{m}^{3}$ on days 29 and 51 respectively. Decreased air contamination was registered with microbes growing on meat-peptone agar, mannitol agar with $7.5 \% \mathrm{NaCl}$ and Sabouraud agar till day 29 only, with microbes on Endo agar even on day 51 of age of the chickens. After administration of aerosol at the age of 15 to 51 days, the number of microbes per gram dust decreased with microbes growing on all substrates used.

Two different patterns of continual air disinfection by lactic acid were tested in fattening houses for chicks. Improved state of health was achieved with both of them, while the first pattern only resulted in higher gain of body mass. Pattern I showed a gain by $\mathbf{~} \mathrm{g}$ per chicken higher and pattern II by $4 \mathrm{~g} /$ chicken lower than the blank turn of chickens. The differences were of no economical significance. With both programs, the mean consumption of lactic acid was $90 \mathrm{mg} /$ day. With program I, there was no difference in microbial contamination of dust in experimental and control houses.
\end{abstract}

Aerosol disinfection, lactic acid, fattening of chickens, bedding.

Being an intermediary product of metabolism, lactic acid belongs to the preparations convenient for continual disinfection of byres with animals housed during its administration. According to Vaškov and Astafjev (1951) in Janíková (1970), vapour of lactic acid in the concentration of $200 \mathrm{mg} / \mathrm{m}^{3}$ air showed no toxic effect on laboratory animals even when systematically administered for several months. In common spaces for humans, the doses recommended for disinfection of air range around $10 \mathrm{mg} / \mathrm{m}^{3}$ (Karpu ch in 1963). Doses of approximately $50 \mathrm{mg} / \mathrm{m}^{3}$ were administered in animal housings (Jarnych 1972; Vorobjev 1973) and, for food storehouses, Matyás (1958) recommended $95-150 \mathrm{mg} / \mathrm{m}^{3}$.

The present report describes results of testing disinfection by lactic acid in laboratory trials and in fattening halls for chickens on bedding.

\section{Materials and Methods}

Laboratory trials were carried out in an airtight fume cupboard of $1.2 \mathrm{~m}^{3}$. Solutions of lactic acid were sprayed by means of the apparatus Mistral forming a comparatively fast sedimenting aerosol. Carriers with microbial cultures on Petri dishes were placed on the bottom level of the fume cupboard and kept there for 30 minutes or $\mathbf{4 8}$ hours respectively after exposure to spraying. Then the carriers were immerged into undiluted phosphate buffer in order to interrupt the action of the 
lactic acid, and, after 10 minutes transferred to meat-peptone broth or, in the case of $E$. coli strains, to Chejfec substrate. During exposure, the carriers were protected by a layer of $2 \%$ agar. From half of them the protective layer has been shaken off either in the liquid substrate or in the phosphate buffer. Results were read after 48 hours of incubation at $37^{\circ} \mathrm{C}$.

The microbial strains used were fowl strains of E. coli, Staphylococcus, Pseudomonas and Bacillus from the collection of the Institut de pathologie aviaire I.N.R.A. at Nouzilly, C.R Z.V. Tours, France. After 24 hours of growth on BHI gelatine broth, the $E$. coli strain had a mean of $9.4 \times 10^{8}$, the Staphylococcus strain $9.1 \times 10^{3}$, the Pseudomonas strain $1.2 \times 10^{8}$ and the Bacillus strain $3.2 \times 10^{7} \mathrm{microbes} / \mathrm{ml}$ substrate. Resistance against phenol after 5 and 10 minutes $(+,-)$ corresponded to dilutions 1:109 with E. coli and Staphylococcus, 1:154 with Pseudomonas and 3:4 with Bacillus. The strains E. coli, Staphylococcus and Bacillus tested by the method of Vaškov (1952) showed to be thermoresistant to temperature of $60^{\circ} \mathrm{C}$ for 35 minutes and to survive the following 6 days. Thermoresistance of Pseudomonas has nct been examined.

For each microbial strain, five sterile filter paper discs of different shape were placed on a Petri dish. Volumes of $0.05 \mathrm{ml}$ of $24 \mathrm{hrs}$ broth cultures diluted up to $10^{-4}$ were administered on each paper carrier. After drying in the incubator, one half of the carriers with the microbes tested were covered by a layer of $2 \%$ meat-peptone agar. As soon as the agar cover congelated, all paper carriers on Petri dishes to be examined were placed in the fume cupboard, while control paper carriers were left in the laboratory.

The field trial with aerosol of lactic acid was carried out in one division of a fattening hall for 3,760 chickens, having a space of $755 \mathrm{~m}^{3}$, and belonging to the farm Rašpach near Třebon̆. The aerosol of particles around $60 \mu$ was produced by two fogging devices Klimatex. The experiment was performed in the summer period. In the course of $6-7$ hours of discontinual aerosol administration the behaviour of chickens was under permanent observation, and, the ventilation was kept permanently operating to maintain temperature and humidity within tolerable limits. Consequently, the total amount of lactic acid rose to $6.2 \mathrm{~g} / \mathrm{m}^{3}$ with chickens aged 15 and 25 days, and to $3.6 \mathrm{~g} / \mathrm{m}^{3}$ with chickens aged 29 and 51 days. In proportion to intensity of ventilation, the concentrations achieved with every administration were $307 \mathrm{mg} / \mathrm{m}^{3}$ lactic acid with chickens of 15 and 25 days, and, $84 \mathrm{mg} / \mathrm{m}^{3}$ with chickens of 29 and 51 days. With five discontinual administrations in the course of disinfection, there was a total of $1,535 \mathrm{mg} / \mathrm{m}^{3}$ and $420 \mathrm{mg} / \mathrm{m}^{3}$ respectively of lactic acid exerting influence on air and dust in the division with chickens.

Air samples were collected on 5 posts at the.level of bedding prior to disinfection and one hour after the last administration of aerosol. The substrates used were meat-peptone agar, Endo agar, mannitol agar with $7.5 \% \mathrm{NaCl}$ and Sabouraud agar. The mean number of microbes per $1 \mathrm{~m}^{3}$ air was calculated by the formula of Spurný et al. (1961).

Simultaneously, $2-4$ samples of dust were collected from the surface of electric hens, ventilators and heaters. They were wiped with sterile paper pads and inserted into sterile test tubes. In the laboratory, the dust samples were processed by the method of successive diluting with saline of $\mathrm{pH} 7.0$, and, $0.1 \mathrm{ml}$ of each dilution were inoculated in different substrates. Cultures on meat-peptone agar and Endo agar were kept for 24 hours, cultures on mannitol agar with $7.5 \% \mathrm{NaCl}$ for 72 hours in the incubator at $37^{\circ} \mathrm{C}$, cultures on Sabouraud agar for 5 days at room temperature. Then colonies were counted and numbers of microbes $/ 1 \mathrm{~g}$ dust calculated.

Another testing of lactic acid aerosol was carried out in the course of two fattening turns in double-halls for chickens kept on bedding at Židlochovice. The capacity of the halls was 10,000 chickens each. The halls were equipped with the device Funki and environmental conditions were controled automatically. Fodder for both feeding lines was supplied from a common storage tank. One hall was selected for the experiment, the second served for control. Chickens were delivered to both halls from one hatchery at the same time.

During the first turn, chickens of 14 to 50 days of age vere housed in the halls. Three fogging devices Klimatex were installed in the experimental hall. With chickens aged 14 and 15 days, $1,350 \mathrm{mg} / \mathrm{m}^{3}$ lactic acid were sprayed each day. During the following period of 34 days, $90 \mathrm{mg} / \mathrm{m}^{3}$ were administered daily. The Klimatexes were operated 6 times for 30 minutes daily while the ventilators were switched off. During the second turn, lactic acid was sprayed as soon as the first day of life of the chickens. From day 1 to 7 , the amount sprayed was $45 \mathrm{mg} / \mathrm{m}^{3}$, from day 8 to 49 , it was $90 \mathrm{mg} / \mathrm{m}^{3}$.

The state of health of chickens was under control by post-mortem examinations of dead birds, by inspection in the slaughterhouse at Modřice, by examination of a part of blood sera from slaugh tered chickens for precipitating antibodies against adenoviruses by means of the FAV-1 (CELO) antigen, and, by evaluation of mortality and growth rates in the course of fattening.

With the first turn, samples of dust were collected from equipments in both halls, and, examined by the method of successive diluting for quantity of microbes growing on MPA, Endo agar, mannitol agar with $7.5 \% \mathrm{NaCl}$, and on Czapek-Dox agar. 


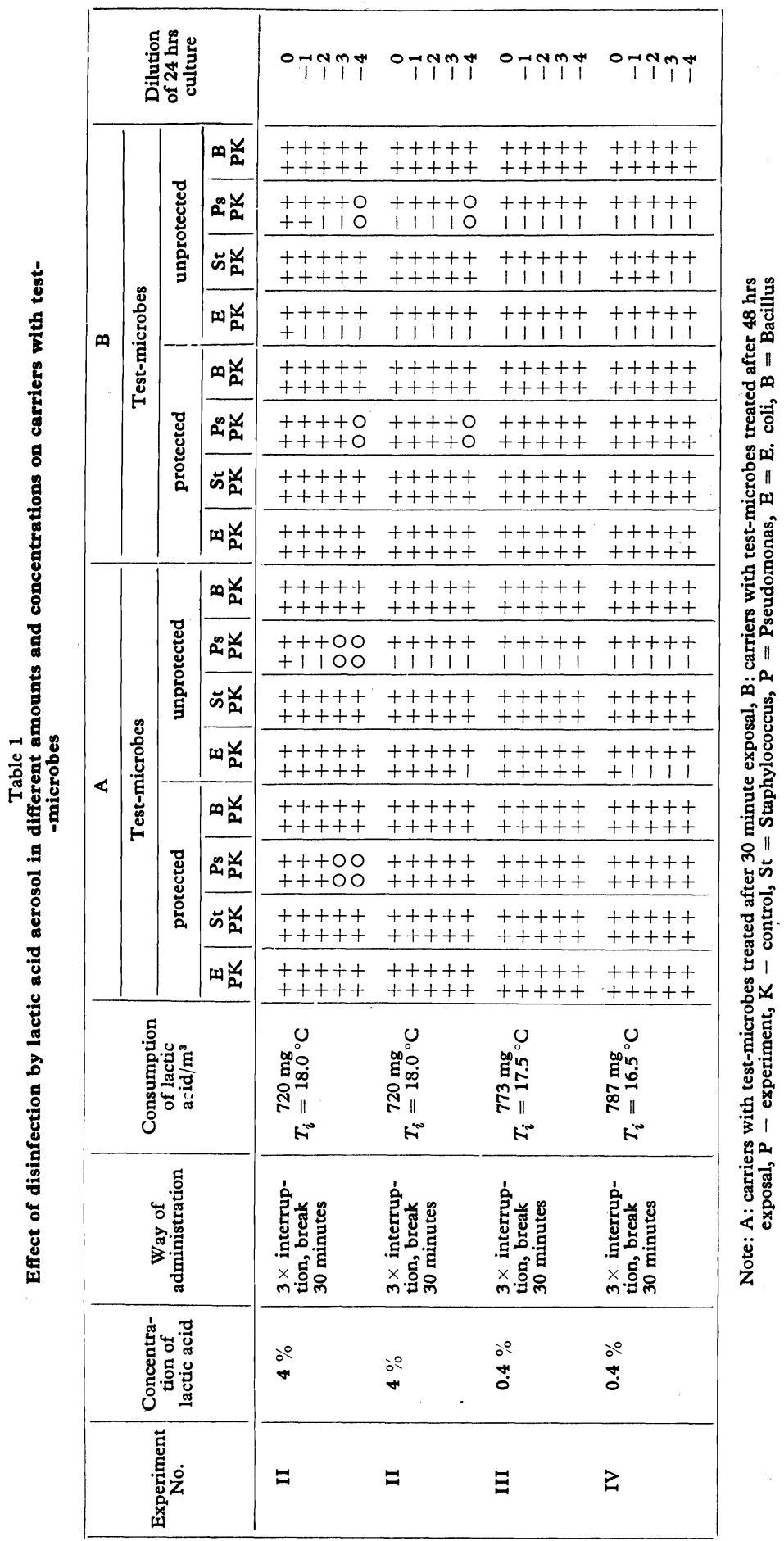




\section{Results}

The results are illustrated in Tables $1,2,3,4$, and, in Figures 1 and 2.

From Tab. 1 it is evident that all strains protected by agar layer survived 30 minutes and 48 hours following disinfection in spite of the high doses of 720 to $787 \mathrm{mg} / \mathrm{m}^{3}$ of lactic acid sprayed. Without protection, Pseudomonas strains only were devitalized, E. coli partly, and, after 40 hours Staphylococcus also. The Bacillus strain remained resistant to the aerosol of lactic acid.

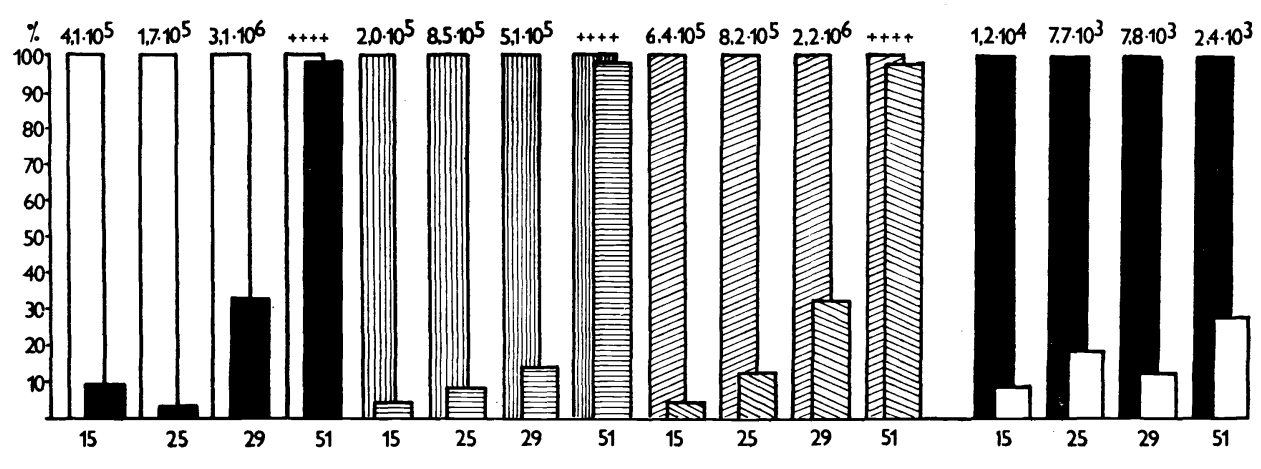

Fig. 1.

Microbial contamination of $1 \mathrm{~m}^{3}$ air in the fattening hall for chickens on bedding prior (100\%) and following ( $\mathrm{X} \%$ ) disinfection of air by aerosol of lactic acid.

$x$-axis: age of chickens in days

$y$-axis: numbers of microbes (in \%). $100 \%$ corresponds to values prior to disinfection which are noted above the columns in the figure

+ disinfection carried out without collecting samples of dust

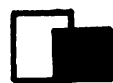

microbes growing on meat-pepton agar

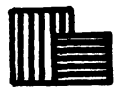

microbes growing on mannitol agar with $7.5 \% \mathrm{NaCl}$

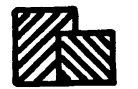

microbes growing on Sabouraud agar

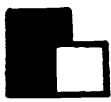

microbes growing on Endo agar

From Fig. 1 it can be seen that disinfection of air in the hall by lactic acid aerosol administered in the large amounts of $1.535 \mathrm{mg} / \mathrm{m}^{3}$ and $420 \mathrm{mg} / \mathrm{m}^{3}$ was efficient against microbes growing on MPA, mannitol agar with salt and Sabouraud agar till 4 weeks only (chickens aged 29 days). With microbes growing on Endo agar, their quantity decreased successively $\left(1.2 \times 10^{3}, 7.7 \times 10^{3}, 7.8 \times 10^{3}\right.$, $2.4 \times 10^{3}$ ) from day 15 to day 51 . Compared with the numbers prior to disinfection and at $7-8$ weeks (chickens 51 days of age), more than $60 \%$ of microbes were devitalized by lactic acid aerosol. 
Fig. 2 illustrates that at day 51, microbial contamination of air was substantially higher than at days 29,25 , and 15 , but, disinfection by aerosol of lactic acid resulted in spite of that in devitalization of the microbes examined.

Table 2

State of health and working indicators. Turn 1 - fattening of chickens

\begin{tabular}{|c|c|c|c|c|}
\hline I. Pathological findings & & al hall & \multicolumn{2}{|c|}{ Control hall } \\
\hline $\begin{array}{l}\text { Volvulus } \\
\text { Enteritis } \\
\text { Suffocation } \\
\text { Mycoplasmosis } \\
\text { no finding } \\
\text { Haemorrhagic syndrom } \\
\text { Rupture of liver }\end{array}$ & $\begin{array}{r}1 \times \\
16 \times \\
5 \times \\
3 \times \\
4 \times \\
1 \times \\
2 \times\end{array}$ & $\begin{array}{r}3.12 \% \\
50.00 \% \\
15.62 \% \\
9.38 \% \\
12.50 \% \\
3.12 \% \\
6.25 \%\end{array}$ & $\begin{array}{l}0 \\
17 \times \\
4 \times \\
1 \times \\
0 \\
4 \times \\
1 \times\end{array}$ & $\begin{array}{r}0 \% \\
63.00 \% \\
14.80 \% \\
3.70 \% \\
0 \% \\
14.80 \% \\
3.70 \%\end{array}$ \\
\hline \multicolumn{5}{|c|}{ Parasitological examination negative with all samples } \\
\hline \multicolumn{5}{|l|}{ II. Inspection in slaughterhouse } \\
\hline $\begin{array}{l}\text { Mortality due to transportation } \\
\text { Fit under precautions: } \\
\text { Leucosis } \\
\text { Marek's disease } \\
\text { Mycoplasmosis } \\
\text { other disease } \\
\text { Confiscation due to pathologicals changes: } \\
\text { Emaciation } \\
\text { other } \\
\text { Confiscation due to technological } \\
\text { defficiencies: } \\
\text { slaughtered in agony } \\
\text { mechanical damage }\end{array}$ & & $\begin{array}{l}\text { is }(=20 \mathrm{~kg}) \\
\text { is } \\
\text { is } \\
\text { is } \\
\text { is }\end{array}$ & & $\begin{array}{l}\text { is }(=20 \mathrm{~kg}) \\
\text { is } \\
\text { is } \\
\text { is } \\
\text { is } \\
\text { is }\end{array}$ \\
\hline \multicolumn{5}{|c|}{$\begin{array}{l}\text { III. Serological examination of blood sera for presence of precipitation antibodies against adenoviruses (antigen } \\
\text { FAV-1 (CELO) }\end{array}$} \\
\hline & \multicolumn{2}{|c|}{ No positive from 98 samples } & \multicolumn{2}{|c|}{$\begin{array}{c}\text { Seven from } 96 \text { samples }(7.3 \%) \\
\text { positive }\end{array}$} \\
\hline \multicolumn{5}{|l|}{ IV. Working indicators: } \\
\hline $\begin{array}{l}\text { housed day } 1 \\
\text { housed day } 51 \\
\text { body mass/chicken } \\
\text { mortality } \\
\text { quality } \\
\text { food consumption of both groups }\end{array}$ & \multicolumn{2}{|c|}{$\begin{array}{c}9.926 \text { chicks } \\
9,695 \text { chicks }(13,990 \mathrm{~kg}) \\
1.44 \mathrm{~kg} \\
231 \mathrm{chicks} / 2.39 \% \\
90.15 \%-\mathrm{I} . \text { category } \\
2.211 \mathrm{~kg}\end{array}$} & \multicolumn{2}{|c|}{$\begin{array}{c}\text { 9,926 chicks } \\
9,661 \text { chicks }(13,530 \mathrm{~kg}) \\
1.40 \mathrm{~kg} \\
265 \text { chicks } / 2.74 \% \\
90.00 \%-\mathrm{I} . \text { category } \\
2.211 \mathrm{~kg}\end{array}$} \\
\hline
\end{tabular}

Tab. 2 demonstrates that $7.3 \%$ of blood sera showed antibodies against adenoviruses in the control hall while no positive reactions were registered in the experimental hall (III). Neither were observed in the slaughterhouse pathological changes due to leucosis, Marek's disease, mycoplasmosis or other diseases (II). Working indicators were less convincing, though mortality was lower and body mass gain a little higher than in the control hall (IV).

From Tab. 3 it can be seen that the lactic acid administered had no effect on the number of microbes $/ \mathrm{g}$ dust. Obviously the administered dose of $15 \mathrm{mg} / \mathrm{m}^{3}$ $\left(90 \mathrm{mg} / 6 \mathrm{~m}^{3}\right.$ ) which sedimented on the surface of equipments, displayed no dis- 


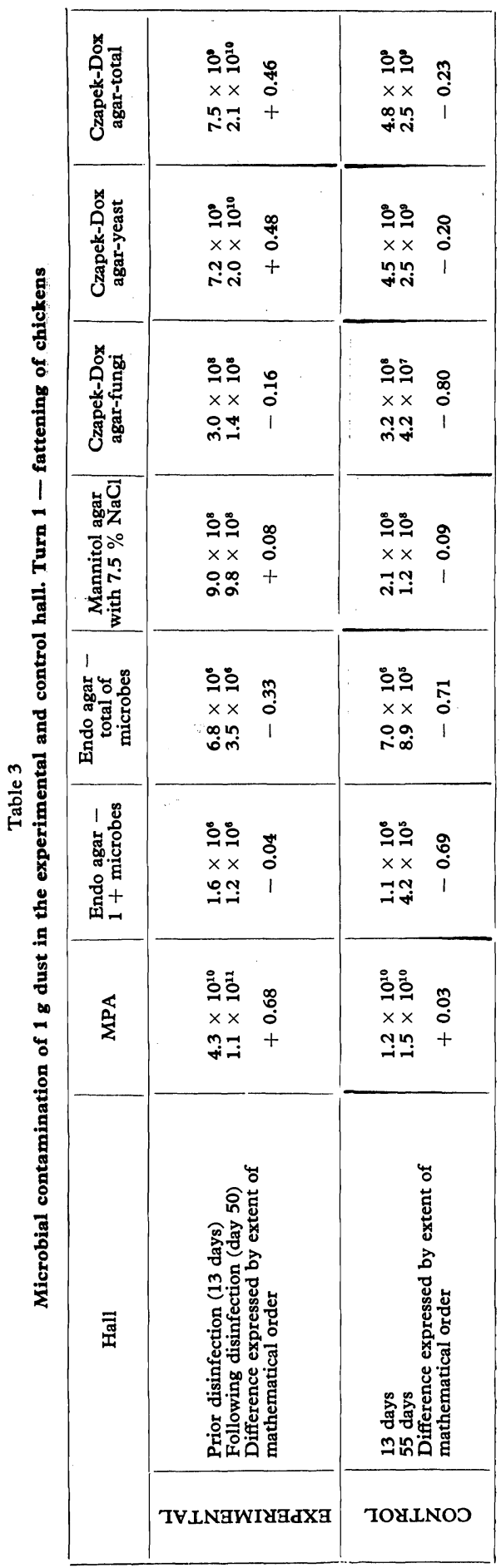




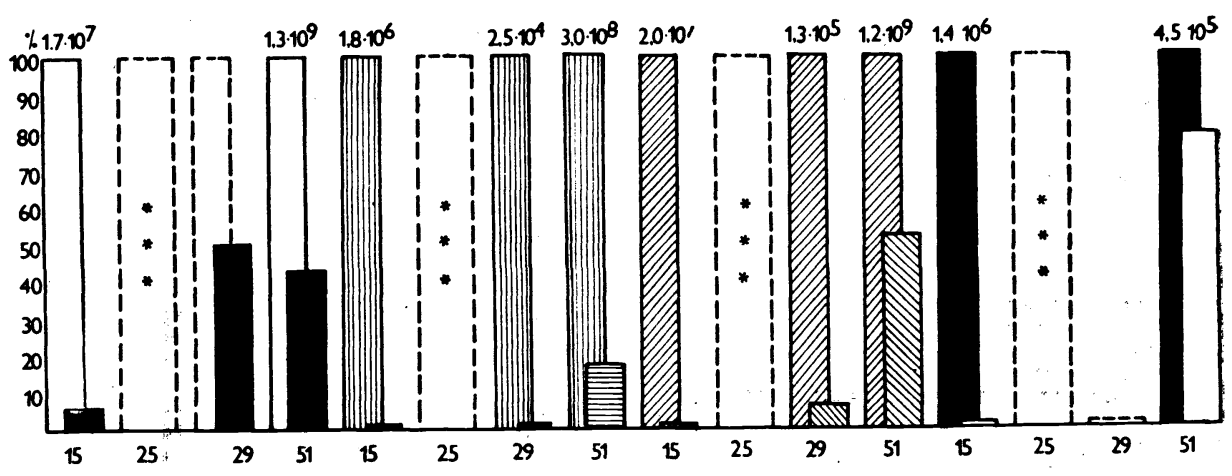

Fig. 2.

Microbial contamination of $1 \mathrm{~g}$ dust in the fattening hall for chickens on bedding prior to $(100 \%)$ and following $(X \%)$ disinfection of air by aerosol of lactic acid.

$x$-axis: age of chickens in days

$y$-axis: numbers of microbes (in \%). $100 \%$ corresponds to values prior to disinfection which are noted above the columns in the figure

+ disinfection carried out without collectirg samples of dust

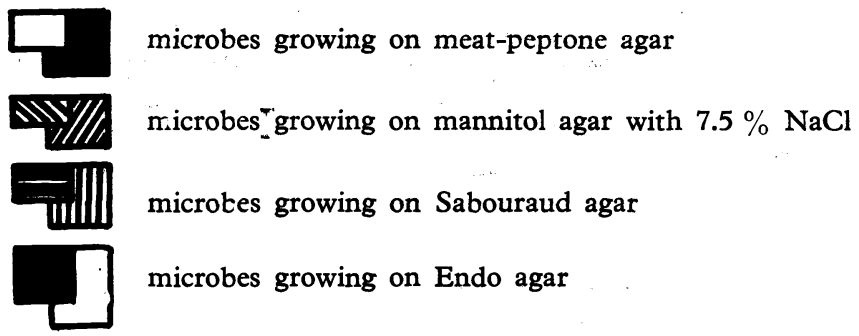

infecting effect by moistening the mixture of secondarily falling dust particles. The dust samples were indeed loose and of dry consistency.

As it results from Tab. 4, most indicative was the effect of lactic acid aerosol when the presence of precipitating antibodies against adenoviruses was tested in blood serum samples. Here again, there were fewer positive reactions in the experimental hall than in the control hall (III: $17.5 \%: 32.1 \%$ ). Inspection of slaughtered chickens also showed a better situation in the experimental hall (II) than in the control hall $(1.79 \%: 2.08 \%)$. Nevertheless, body mass gain was higher with controls $(1.42 \mathrm{~kg})$ than with chickens from the experimental hall (IV : $1.38 \mathrm{~kg})$.

\section{Discussion}

Laboratory trials concerning the effect of lactic acid on $24 \mathrm{hrs}$ microbial cultures already showed that even the comparatively high dosis of $720-787 \mathrm{mg} / \mathrm{m}^{3}$ devitalized only microbes with the level of resistance of Pseudomonas and E. coli strains. By longer exposure in unprotected environment, microbial species on the level of resistance of Staphylococcus were devitalized as well. From Tab. 1 it is also evident that 
Table 4

State of health and working indicators. Turn 2 - fattening of chickens

I. Post-mortem: In consequence of experience from turn 1 no post - mortem examination carried out

II. Inspection in slaughterhouse:

\begin{tabular}{l|c|c}
\hline & Experimental hall & Control hall \\
\cline { 2 - 3 } Fit under precautions: & & 14 \\
Marek's disease & 8 & 5 \\
Mycoplasmosis & 9 & 8 \\
other diseases & 6 & 11 \\
Confiscation due to pathological changes: & 17 & 14 \\
Emaciation & 3 & 14 \\
Haematomas & 7 & 12 \\
Other changes \\
Confiscation due to technological
\end{tabular}

III. Serological examination of blood sera for presence of precipitation antibodies against adenoviruses (antigen FAV-1 (CELO)

14 from $80(=17.5 \%)$ positive

IV. Working indicators:

housed day 1

housed day 51

body mass/chicken

mortality

quality

food consumption for both groups

age of chickens
9.732 chicks

9.540 chicks $(13.180 \mathrm{~kg})$

$1.38 \mathrm{~kg}$

192 chicks $/ 1.97 \%$

$90.0 \%-$ I. cat.

$2.450 \mathrm{~kg}$

50 days
26 from $81(=32.1 \%)$

positive

dilutions of $4 \%$ were less effective than dilutions of $0.4 \%$. With $0.4 \%$ dilutions administered, the amount of lactic acid was by $50-60 \mathrm{mg}$ higher, the volume of dilution was 10 times larger and so was the amount of aerosol sedimented on the bottom of the exposed Petri dish containing the microbes tested. This appears to be the decisive factor when Staphylococcus strains without protective agar layer were devitalized after $48 \mathrm{hrs}$ exposure following administration of aerosol. The conclusion is supported by results with $5 \%$ and $7.5 \%$ dilutions of lactic acid, not recorded in the Table. The amounts of $833.3 \mathrm{mg}$ and $2.108 \mathrm{mg} / \mathrm{m}^{3}$ respectively resulted after 30 minutes of exposure in the first case only in devitalization of the Pseudomonas strain and that with the highest dilution of $10^{-4}$, and in the second case, in devitalization of Pseudomonas and $E$. coli strains with dilutions of $10^{-4}$ to $10^{-2}$. Microbial species protected by an agar layer, could not be devitalized after 30 minutes of exposure, regardless to the degree of dilution, as had been demonstrated in supplementary trials by Fišer (1977).

Results of the field trial are illustrated on Fig. 1 and 2. A partial decrease of microbial contamination of air and dust could be registered not earlier than after 5 separated administrations of aerosol sprayed in comparatively large amounts of $1.535 \mathrm{mg}$ and $420 \mathrm{mg} / \mathrm{m}^{3}$ respectively. The term ,partial decrease" is to be underlined since effectivity was registered in per cent, and consequently, the decrease in number of microbes ranged within one mathematical order. Thus, even after disinfection by aerosol, the microbial contamination of air and dust in the hall with fattened chickens remained on a high level when compared with 
values noted prior to disinfection and at different days of examination (days 15, 25., 29. and 51. of age of chickens). In addition, dust samples wiped from the surface of electrical hens and heaters after disinfection were wet and pasty so that a prolonged effect of sedimented aerosol on the microflora of the secondarily fallen dust could be assumed. The best cumulative effect was observed after the third disinfection (at the age of 29 days of the chickens housed). Already prior to this disinfection, sporulates only were grown on MPA from dust, and, the number of microbes on mannitol agar with salt and Sabouraud agar was by two mathematical orders lower than with chickens aged 15 days. Neither before nor after this disinfection, microbes from dust were grown on Endo agar (Fig. 2). Microbial contamination of the bedding which is the primary source of dustiness, was not examined presently. However, experience with dynamics of microbes in bedding in the course of fattening chickens (Fiš er 1977), and, with difficulty in disinfecting bedding by gaseous formaldehyde (Fiš er 1978), permits to assume that aerosol of lactic acid has no effect on the contamination of bedding. From results reported by Cole et al. (1968) the conclusion can be made that sedimented lactic acid exerts a favourable effect on the organism of chickens. In agreement with the results in Fig. 1 are also the results described by Devos (1971) who achieved decrease in airborne microflora not longer than to the fifth week of life of chickens, when different preparations were sprayed in halls for fattening chickens. Unlike ours, his chickens had a higher final body mass while their feed consumption index was lower.

From our two field trials, only chickens in the first one were heavier than controls to the end of the fattening turn. In both trials, nevertheless, continual disinfection by aerosol of lactic acid resulted in an improved state of health of chickens. Their mortality was lower, few blood serum samples showed the presence of precipitation antibodies against adenoviruses, less pathological changes were detected by inspection in the slaughterhouse. The importance of lactic acid aerosol for controlling infectious laryngotracheitis and for improving generally the state of health in poultry has been emphasized by Jarnych (1972). Thus, disinfection by lactic acid in the form of aerosol is a recommendable procedure but, according to our present results, a higher dose than $90 \mathrm{mg} / \mathrm{m}^{3}$ and interrupted administration have to be considered. In order to improve the effect on the microflora of air and dust, amounts of $300-400 \mathrm{mg} / \mathrm{m}^{3}$ appear to be necessary.

Acknowledgement: The author is indebted to Dr. V. Jurajda, Ph. D., Dept. for Poultry Diseases, University of Veterinary Science, Brno, for his examination of blood sera concerning precipitation antibodies against adenoviruses, and, for post-mortem examination of dead chickens.

\section{Dezinfekce ovzduši a prachu v hale pro kư̌ata ve výkrmu aerosolem kyseliny mléčné}

Kyselina mléčná aplikovaná formou aerosolu devitalizovala $\mathrm{v}$ laboratorních pokusech při dávkách 720 až $787 \mathrm{mg}$ na $1 \mathrm{~m}^{3}$ prostoru po 30 minutách od skončení aerolizace kmeny Psedomonas a $E$. coli a po 48 hodinách od skončení aerolizace i kmeny Staphylococcus.

$\mathrm{V}$ provozních pokusech bylo dosaženo sniženi mikrobiální kontaminace ovzduší $\mathrm{v}$ oddělení s kuřaty na podestýlce při celkové dávce kyseliny mléčné aplikované přerušovaně v množství $1.535 \mathrm{mg} 15$. a 25 . den a $420 \mathrm{mg} 29$. a 51 . den u mikrobů rostoucích na masopeptonovém agaru, na mannitovém agaru s $7,5 \% \mathrm{NaCl}$ a na 
Sabouraudově agaru pouze do 29 dnů stář́i kuřat. U mikrobů na Endově agaru bylo prokázáno snižení i u kư̌at ve stáří 51 dnů. V $1 \mathrm{~g}$ prachu bylo prokázáno sníženi množství mikrobů rostoucích na všech uvedených půdách včetně Endova agaru od 15. až do 51. dne stáři kuřat po aplikaci dezinfekčního aerosolu kyseliny mléčné.

Při ověřování dvou různých programů kontinuální aerosolové dezinfekce ovzduší hal pro výkrm kuřat kyselinou mléčnou bylo dosaženo zlepšení zdravotního stavu kuřat, avšak zvýšeni hmotnosti kư̌at na konci výkrmového turnusu při jejich vyskladnění bylo prokázáno pouze při použití prvního programu. Zvýšení hmotnosti na 1 kus o $4 \mathrm{~g}$ u kuřat vyskladněných $\mathrm{z}$ pokusné haly neovlivnilo ekonomickou efektivitu pokusného turnusu ve srovnání $s$ kontrolním turnusem při aplikaci prvého programu kontinuální dezinfekce, stejně jako nebyla ovlivně̀na ekonomická efektivita kontrolního turnusu kuřat při aplikaci druhého programu kontinuální dezinfekce při zvýšení hmotnosti vyskladněných kư̌at oproti pokusnému turnusu kuřat rovněž o $4 \mathrm{~g}$ na 1 kus. $\mathrm{V}$ obou programech byla prưměrná denní spotřeba kyseliny mléčné na $1 \mathrm{~m}^{3}$ vzduchu $90 \mathrm{mg}$. Mikrobiální kontaminace $1 \mathrm{~g}$ prachu v pokusné a kontrolní hale při plněni prvního programu nebyla rozdílná

\section{Дезинфекция атмосферы и пыли в цыплятнике для откорма цыплят аэрозолью молочной кислоты}

Молочная кислота, применяемая формой аэрозоли, дезинфицировала в лабораторных опытах дозой $720-787$ мг 1 м $^{3}$ пространства спустя 30 минут после окончания аэролиза штаммы Pseudomonas и $E$. coli и спустя 48 часов после окончания аэролиза также штамм Staphylococcus .

В проводимых непосредственно в цыплятнике опытах было достигнуто понижения микробной контаминации атмосферы в отделении с цыплятами на подстилке при общей дозе молочной кислоты, применяемой с перерывами в количестве 1.535 мг на 15 и 25 день и 420 мг на 29 и 51 день у микробов, растущих в мясо-пептонном и маннитном агарах с 7,5 НаСл и в агаре Сабурода лишь до 29 дней возраста цыплят. У микробов в агаре Энда было выявлено понижение также у цыплят в возрасте 51 день. В 1 г пыли было установлено понижение микробов, растущих во всех вышеприведенных агарах, включая агар Энда, с 15 по 51 день возраста цыплят после использования дезинфекционной аэрозоли молочной кислоты.

В ходе проверки двух разных программ непрерывной аэрозольной дезинфекции атмосферы цыплятников для откорма цыплят молочной кислотой было достигнуто улучшения состояния здоровья цыплят, однако, увеличение массы цыплят к конщу цикла откорма было доказано лишь при использовании первой программы. Увеличение массы на 1 голову на 4 г цыплят, отправленных из подопытного цыплятника, не оказало влияния на экономическую эффективность опытного цикла по сравнению с контрольным циклом при использовании первой программы непрерывной дезинфекции и в одинаковой степени не наблюдалось никакого влияния на экономическую эфФективность контрольного цикла цыплят при применении второй программы непрерывной дезинфекции при увеличении массы отправленных цыплят по сравнению с подопытными цыплятами также на 4 г на голову. В обеих программах средний суточный расход молочной кислоты на $1 \mathrm{~m}^{3}$ воздуха достигал 90 мг. Микробная контаминация 1 г пыли в опытном и контрольном цыплятниках при выполнении первой программы не отличалась разницей. 


\section{References}

COLE, D. J. A. - BEAL, R. M. - LUSCOMBE, J. R.: The effect on performance and bacterial flora of lactic acid, propionic acid, calcium propionate and calcium acrylate in the drinking water of weaned pigs. Veterinary Record, 83, 1968: 459-464.

DEVOS, A.: Influence de la désinfection répétée sur la pollution atmosphérique des poulaillers et sur la production de poussiers á l'engraissement. Récueil de Médecine vétérinaire 1971, CXLVII: $1335-1347$.

FIŠER, A.: Dynamika mikrobiální kontaminace prostředí při výkrmu kuřat na podestýlce. Veterinářství, 17, 1977: 514-515.

FIŠER, A.: Mikrobiální kontaminace velkokapacitních stáji a možnosti jejího ovlivnění aerosolovou dezinfekcí v přitomnosti zviřat. Thesis, Brno 1977, pp. 176.

FIŠER, A.: Ưčinnost paraformaldehydové pěny při kontinuálni dezinfekci drůbeži podestýlky a sušeného tekutého hnoje prasat. Vet. Med. Praha 1978, in press.

JANÍČKOVA, L.: Dezinfekční aerosoly. Studijní informace - Veterinářství. Praha 1970, ÚVTI, č. 2 , p. 56 .

JARNYCH, V. S.: Aerozoli v veterinarii. Moskva, Kolos 1972, 350.

KARPUCHIN, G. I.: Bakteriologičeskoe issledovanie i obezzaraživanie vozducha. Moskva 1962 GIML, p. 256.

MATYÁS, Z.: K otázce dezinfekce vzduchu aerosolem kyseliny mléčné v potravinářských závodech (Thesis), Brno, 1958, pp. 150.

SPURNÝ, K. - JECH, C. - SEDLÁĊEK, B. - STORCH, O.: Aerosoly. Praha 1961, p. 342.

VAŠKOV, B. I.: Rukovodstvo po dezinsekcii, dezinfekcii i deratizacii. Moskva 1962, GIML Medgiz, pp. 654.

VOROBJEV, S. A.: Dezinfekcija ptičnika v prisutstvii pticy. In: Trudy VNITIP, Moskva 1973, 37: $189-192$. 